\title{
Peran Guru Dalam Penerapan Nilai-Nilai Ta'lim Al-Muta'allim Dalam Pembelajaran Di MTSN Plandi Jombang
}

\author{
Sunardi \\ Prodi Manajemen Pendidikan Islam (MPI), STIT al Urwatul Wutsqo - \\ Jombang, Indonesia \\ sunardi.ppuw@gmail.com
}

\begin{abstract}
Menurut Ali Syafe"i Manusia adalah makhluk yang tertinggi derajatnya yang diciptakan Tuhan yang terbaik, terhormat, mulia, individu, sosial, makhluk bumi pengemban amanat. Sejalan dengan ketinggian dan kerendahan manusia dalam menjaga kelansungan dan potensi hidupnya agar tidak mati atau menjadi liar, maka perlu dilakukan pembinaan dan bimbingan terhadap potensi yang dimilikinya agar dapat berkembang dengan benar dan terarah. Oleh karena itu, pendidikan merupakan alternatif penting manusia untuk membina potensinya. Sementara posisi guru dalam pembelajaran merupahan sebagai transper ilmu pengetahuan (knowledge oriented) dan ketrampilan (skill oriented), namun juga berorientasi pada nilai (vules oriented). Proses pembelajaran yang menekankan pada nilai-nilai (kejujuran, keharmonisan, saling menghargai, dan kesetaraan) adalah hal yang tidak disampingkan, apalagi dilakukan. Jenis Penelitian ini menggunakan penelitian lapangan (field reasearch) dan menggunakan pendekatan kualitatif yang bersifat deskriptif, dengan rancangan teknik
\end{abstract}




\section{Sunardi}

pengumpulan data melalui wawancara, observasi, dan dokumentasi. Teknik analisis data menggunakan metode deskriptif analisis kualitatif. Hasil penelitian ini model pembeljarannya adalah menggunakan: metede ceramah, metode diskusi, metode tanya jawab, dan metode pemberian tugas. Sedangkan peran guru dalam meng implementasi nilai-nilai Ta"lim al-Muta" allim dalam pembelajaran adalah:a. Guru sebagai pembimbing, b. Guru sebagai tauladan, c. Guru sebagai pengajar sekaligus sebagai pendidik, e. Pembiasaan.

Keywords: Implementasi, Nilai-nilai, Pembelajaran.

\section{Konteks Penelitian}

Perkembangan zaman yang semakin komplek dan menuju proses ilmu pengetahuan dan teknologi akan selalu membawa perubahan dalam aspek kehidupan, dan kini hal tersebut telah dirasakan dan menyebabkan terjadinya suatu perubahan yang cukup pesat, baik dari segi pendidikan, struktur ekonomi, sosial, budaya dan juga dari segi pola dan gaya hidup, sehingga terjadi pergeseran suatu nilai baik buruk khususnya yang berkaitan dengan norma-norma agama.

Makhluk hidup yang namanya manusia mulai pertama diciptakan sudah membutuhkan pendidikan yang akan menunjang perkembangan dirinya, walaupun untuk memenuhi tuntunan perkembangan hidupnya dibutuhkan suatu tindakan yang efektif yang belum pernah dilakukan untuk dapat menjadikan suatu nilai kebaikan dalam hidupnya. Manusia adalah makhluk ciptaan Allah yang paling istimewa bila dilihat dari sosok beban dan tanggung jawab yang dipercayakan kepadanya. Keistimewaan manusia membedakan dirinya dengan makhluk lainnya yang juga merupakan ciptaan Allah. Sebagai makhluk yang memiliki 


\section{Peran Guru Dalam Penerapan Nilai-Nilai Ta'lim Al-muta'allim}

kelebihan dan keistimewaan, ia dijadikan sosok makhluk yang pantas untuk memimpin dan mengelola bumi. Menurut Ali Syafe ${ }^{e c}$ Manusia adalah makhluk yang tertinggi derajatnya yang diciptakan Tuhan yang terbaik, terhormat, mulia, individu, sosial, makhluk bumi pengemban amanat(Akhyak, 2003:30). Allah menciptakan manusia dimuka bumi ini terdiri dari dua unsur yaitu unsur tanah dan unsur ilahiah. Hal ini tesebut sesuai dengan firman Allah dalam Qs. Shaad : 71-72.

"(ingatlah)"ketika Tuhanmu berfirman kepada malaikat: "sesungguhnya Aku akan menciptakan manusia dari tanah. Maka apabila telah $k u$ sempurnakan kejadiannya dan aku tiupkan kepadanya roh(ciptaan) $k u$, maka hendaklah kamu tersungkur dengan bersujud kepadanya.

Ayat tersebut menerangkan bahwa semua manusia dalam fase ini tidak mempunyai kelebihan yang membuat mereka lebih utama atau lebih tinggi kedudukannya diatas makhluk-makhluk lainya. Pada peniupan ruh Allah mengalirkan dalam wujud manusia nilai-nilai keutamaan yang menjadikan haknya untuk meraih ketinggian, kemuliaan dan kedudukan.

Sejalan dengan ketinggian dan kerendahan manusia dalam menjaga kelansungan dan potensi hidupnya agar tidak mati atau menjadi liar, maka perlu dilakukan pembinaan dan bimbingan terhadap potensi yang dimilikinya agar dapat berkembang dengan benar dan terarah. Oleh karena itu, pendidikan merupakan alternatif penting manusia untuk membina potensinya. Hal ini didasarkan pada kelebihan dan 


\section{Sunardi}

keistimewaan sebagai makhluk yang berakal, sementara disisi lain manusia makhluk pedagogis, artinya dia dapat berfikir, dididik dengan benar dan terarah. Pendidikan merupakan bagian dari proses kehidupan, ia merupakan wahana perubahan pada seseorang, baik kesadaran pribadi, maupun kesadaran mengubah, dan mengontrol lingkungannya.

Didalam Undang-Undang Nomor 20 Tahun 2003 tentang sisitem pendidikan nasional dijelaskan bahwa pendidikan adalah usaha sadar dan terencna untuk mewujudkan suasana belajar dan proses pembelajaran agar peserta didik secara aktif mengembangkan potensi dirinya untuk memiliki kekuatan spiritual keagamaan, pengendalian, kecerdasan, akhlak mulia, serta keterampilan yang diperlukan dirinya, masyarakat bangsa dan negara( H. Rumayulis, 2002:13).

Pendidikan pada umumnya ditujukan untuk menanamkan nilainilai dan norma-norma tertentu sebagaimana yang telah diterapkan dalam filsafat pendidikan, yakni nilai atau norma yang dijunjung tinggi oleh suatu lembaga pendidikan.

Istilah pendidikan seringkali tumpang tindih dengan istilah pengajaran. Oleh karena itu, tidak heran jika pendidikan terkadang juga dikatakan "pengajaran" atau sebaliknya, pegajaran disebut sebagai pendidikan.

Belajar merupakan bagian dari proses pendidikan yang mencakup totalitas keunggulan kemanusiaan sebagai hamba (,,abd) dan pemakmur alam (khalifah) agar senantiasa bersahabat dan memberikan kemanfatan untuk kehidupan bersama. Belajar atau sekolah sama-sama bermakana mencari ilmu yang merupakan bagian penting dari proses 


\section{Peran Guru Dalam Penerapan Nilai-Nilai Ta'lim Al-muta'allim}

pendidikan yang pada intinya adalah transfer ilmu dan nilai moral. Manusia tidak bisa lepas dari kegiatan belajar-mengajar ini. Dengan demikian, belajar dan mengajar sangat penting dalam proses perkembangan seseorang(Mastuhu, 1994: 2).

Sementra pada hakekatnya belajar merupakan suatu proses yang dinilai oleh individu untuk memperoleh perubahan tingkah laku kearah yang lebih baik sebagai hasil dari pengalaman individu dalam interaksi dengan lingkungan. Perubahan tingkah laku sebagai hasil belajar dapat terjadi melalui usaha mendengar, membaca, mengikuti petunjuk, mengamati, memikirkan, menghayati, meniru, melatih atau mencoba sendiri dengan pengajaran atau latihan. Adapun perubahan tingkah laku sebagai hasil belajar tersebut relatif tetap dan bukan hanya perubahan yang bersifat sementara. Tingkah laku mengalami perubahan menyangkut aspek kepribadian, baik perubahan kepribadian, pengetahuan, kemampuan, ketrampilan, kebiasaan, sikap dan aspek prilaku lainnya(H. Rumayulis, 2002:235).

Karena itulah, manhaj pendidikan moral dalam Islam harus dimulai sejak dini. Pada dasarnya, ia merupakan asas yang dipertimbangkan bagi pembinaan keluarga yang kokoh dan harmonis. Sesungguhnya pendidikan moral inilah yang menjamin terwujudnya keluarga Islam yang kuat, yang penuh warna rasa cinta dan menjamin terbentuknya seorang manusia yang sehat tubuh, akal dan jiwanya.

Pendidikan seperti inilah yang kita harapkan yang mendorong kita untuk mengembangkan paradigma baru, pendidikan yang tidak hanya berorientasi pada ilmu pengetahuan (knowledge oriented) dan ketrampilan (skill oriented), namun juga berorientasi pada nilai (vules oriented). Proses pembelajaran yang menekankan pada nilai-nilai 


\section{Sunardi}

(kejujuran, keharmonisan, saling menghargai, dan kesetaraan) adalah hal yang yang tidak disampingkan, apalagi dilakukan(M. Slamet Yahya, 2005:2).

Dalam belajar-mengajar, Islam memberikan cara-cara yang sangat teratur dan sistematis, semua telah diatur untuk memperoleh hasil yang maksimal. Disamping teori-teori belajar menurut para ilmuan barat, jauh sebelum semua itu muncul Islam telah mengatur dalam kitabkitab, buku-buku, seperti dalam kitab Ta"lim al-Muta"allim dan kitabkitab Islam yang lainnya. Kesemuanya itu jika dilaksanankan dalam proses pembelajaran akan memberikan manfaat yang luar biasa.

Sebagaimana penjelasan guru MTsN Plandi Jombang :

"Sekolah merupakan salah satu tempat membina, membimbing, mempersiapkan anak didik, dan tempat bergaul dengan teman sebaya serta tempat berkumpul dengan guru. Oleh karena itu, sangat perlu sekali jika di sekolah atau madrasah diterapkan nilainilai Ta"lim al-Muta"allim dalam pembelajaran. Karena dalam Ta"lim al-Muta"allim ini banyak memuat materi-materi yang mengarahkan siswa untuk selalu bersikap terpuji seperti bagaimana akhlak terhadap guru, orang tua, teman, dan masyarakat serta menjauhi perbuatan-perbuatan dosa atau tercela"(Syamsul Islam, Wawancara, 26 November 2012).

Mengingat pentingnya tujuan pendidikan atau pembelajaran adalah untuk mendidik akhlak dan jiwa, mengarahkan prilaku kepada akhlak yang lebih baik, menanam nilai-niai moral. Maka di MTsN Plandi Jombang juga merupakan salah satu yang melaksanakan hal itu, karena 


\section{Peran Guru Dalam Penerapan Nilai-Nilai Ta'lim Al-muta'allim}

melihat betapa pentingnya penerapan nilai-nilai tersebut yaitu dengan menanamkan nilai-nilai Ta"lim al-Muta" allim dalam pembelajaran.

Sehingga menuntut ilmu bukan sekedar transfer ilmu untuk kepentingan dunia saja, bukan hanya untuk kecerdasan akal saja tampa memikirkan spiritualitas dan akhlak. sehingga belajar haruslah mencakup segala aspek, mulai dari kecerdasan akal hingga kecerdasan akhlak untuk kehidupan sehari-hari. Oleh karena berdasarkan bebrapa pakta dan data yang dipaparkan pada kontek penelitian tersebut maka peneliti menyusun sebuah judul "Implementasi nilai-nilai Ta"lim alMuta"allim dalam pembelajaran di MTsN Plandi Jombang".

\section{Fokus Penelitian}

Berdasarkan konteks penelitian diatas maka fokus penelitian ini adalah sebagai berikut:

1. Pembelajaran Ta"lim al-Muta"allim di MTsN Plandi Jombang

2. Peran guru dalam mengimplementasi nilai-nilai Ta "lim alMuta "allim dalam pembelajaran di MTsN Plandi Jombang

\section{Kajian Pustaka}

A. Pengertian belajar, mengajar dan pembelajaran

1. Pengertian belajar

Menurut Kamus Besar Bahasa Indonesia, secara etimologi belajar memiliki arti "berusaha memperoleh kepandaian atau ilmu". Definisi ini memiliki pengertian bahwa belajar adalah suatu aktivitas seseorang untuk mencapai kepandaian atau ilmu yang tidak dimiliki sebelumnya. Dengan belajar manusia menjadi tahu, memahami, mengerti, serta dapat melaksanakan dan memiliki "sesuatu"(Hari Rahyubi, 2012:1). 


\section{Sunardi}

Para ahli mendefinisikan belajar dengan berbagai rumusan sehingga terdapat keragaman tentang makna belajar.

a. Skinner, berpendapat yang dimaksud belajar adalah suatu prilaku, pada saat orang belajar, maka responnya menjadi lebih baik, sebaliknya bila ia tidak belajar maka responya menurun.

b. Gagne, merumuskan bahwa belajar merupakan kegiatan yang kompleks, yaitu setelah belajar orang memiliki ketrampilan, pengetahuan, sikap dan nilai.

c. Henry Clay Lingren dan Newtin suter mendefinisikan dengan perubahan yang relatif permanen dalam bentuk tingkah laku yang terjadi sebagai hasil pengalaman.

d. James W. Zanden, mengatakan bahwa belajar adalah perubahan tingkah laku yang relatif permanen atau perubahan kemampuan sebagai hasil dari pengalaman. Sebagai proses yang didapatkan dari penambahan yang relatif stabil yang terjadi pada tingkah laku individu yang berinteraksi dengan lingkungan.

Belajar juga memilki pengertian memperoleh pengetahuan atau menguasai pengetahuan melalui pengalaman, mengingat, menguasai pengalaman, dan mendapatkan informasi atau menemukan. Dengan demikian, belajar memiliki arti dasar adanya aktivitas atau kegiatan dan penguasaan tentang sesuatu. Belajar adalah proses transformasi ilmu guna memperoleh kompetensi, ketrampilan, dan sikap untuk membawa perubahan yang lebih baik. 
Belajar merupaka aktivitas menuju kehidupan yang lebih baik secara sistematis. Proses belajar terdiri atas tiga tahapan, yaitu tahap informasi, transformasi, dan evaluasi. Yang dimaksud dengan tahap informasi adalah proses penjelasan, penguraian, atau pengarahan mengenai prinsip-prinsip struktur pengetahuan, ketrampilan dan sikap. Tahap transformasi adalah proses peralihan atau perpindahan prinsip-prinsip struktur tadi kedalam diri pesrta didik. Proses transfprmasi dilakukan melalui informasi. Namu, informasi itu harus dianalisis, diubah, atau ditransformasikan kedalam bentuk yang absrtak atau konseptual agar dapat digunakan dalam konteks yang lebih luas"(Hari Rahyubi, 2012:3).

Syaiful Bahri Djamah menjelaskan bahwa belajar pada hakikatnya adalah "perubahan" yang terjadi dalam diri seseorang setelah berahir melakukan aktifitas belajar, walaupun pada kenyataannya tidak semua perubahan termasuk kata gori belajar(H. Rumayulis, 2002:235).

2. Pengertian mengajar

Pengajaran atau yang biasa disebut dengan istilah mengajar amat dekat dengan pengertian pedagogi. Pedagogi adalah seni atau ilmu untuk menjadi guru, istilah ini sering mengacu kepada strategi pengajaran atau gaya mengajar. William H. Burton, seorang behavioris, menyatakan bahwa mengajar adalah upaya memberikan stimulus, bimbingan, pengarahan, dan dorongan kepada siswa agar terjadi proses belajar(Suyono, 2011:16).

Dalam masalah mengajar juga terdapat keragaman para ahli fisikologi pendidikan dalam mendifinisikannya. 


\section{Sunardi}

a. H.M. Arifin merumuskan pengertian mengajar sebagai suatu kegiatan penyampaian bahan pelajaran kepada pelajar agar dapat menerima, menanggapi, menguasai, dan mengembangkan bahan pelajaran itu.

b. Roestiyah NK menyatakan, mengajar adalah bimbingan kepada anak dalam proses belajar.

c. Hasan langgulung mendefinisikan pengajaran adalah pemindahan pengetahuan dari seseorang yang mempunyai pengetahuan kepada orang lain yang belum mengetahui(H. Rumayulis, 2002:238).

3. Pengertian pembelajaran

Pembelajaran secara sederhana dapat diartikan sebagai sebuah usaha mempengaruhi emosi, intelektual, dan spiritual seseorang agar mau belajar dengan kehendaknya sendiri. Melalui pembelajaran akan terjadi proses pengembangan moral keagamaan, aktivitas, dan kreativitas peserta didik melalui berbagai interaksi dan pengalaman belajar. Pembelajaran berbeda dengan mengajar yang pada prinsipnya menggambarkan aktivitas guru, sedangkan pembelajaran menggambarkan aktivitas peserta didik. Beberapa ahli merumuskan pengertian pembelajaran.

a. Menurut Syaiful Sagala, pembelajaran ialah membelajarkan siswa menggunakan azaz pendidikan atau teori belajar yang merupakan penentu utama keberhasilan pendidikan.

b. Menurut Cory, pembelajaran adalah suatu proses dimana lingkungan seseorang secara disengaja dikelola untuk memungkinkan ia turut serta dalam tingkah laku dalam 


\section{Peran Guru Dalam Penerapan Nilai-Nilai Ta'lim Al-muta'allim}

kondisi khusus atau menghasilkan respon terhadap situasi tertentu.

\section{Metode Penelitian}

Penelitian tentang Implementasi nilai-nilai Ta ${ }^{\text {ee }} \mathrm{lim}$ al-Mutaeallim dalam pembelajaran di MTsN Plandi Jombang ini menggunakan jenis penelitian lapangan (field research) menggunakan paradigma penomenologi dan pendekatan penelitian kualitatif. Sumber penelitian ini meliputi orang yaitu kepala sekolah, waka kurikulum, waka kesiswaan, guru mata pelajaran dan siswa. Sumber data yeng berupa tempat adalah sarana, dan prasarana kerja dan aktivitas di MTsN Plandi Jombang sedangakan data sekunder berupa dokumen, yaitu beberapa arsip sekolah yang berkaitan dengan profil MTsN Plandi Jombang, dokumen, buku-buku, catatan-catatan, buku absen, buku rapat dan lain sebagainya yang berkaitan dengan penelitian ini.

Teknis pengupulan data dalam penelitian ini menggunakan Interview (wawancara), observasi dan dokumentasi. Sedangkan teknis analisis data penelitian ini menggunakan redukasi data, penyajian data dan verifikasi data.

\section{Pembahasan}

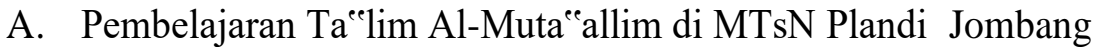

1. Tujuan pembelajaran Ta $\mathrm{Ta}^{\mathrm{ec}} \mathrm{lim}$ al-Mutallim di MTsN Plandi Jombang

Tujuan dalam pembelajaran merupakan masalah yang sangat sentral, sebab tampa perumusan yang jelas tentang tujuan pembelajaran, perbuatan tersebut menjadi acak-acakan, tampa arah, bahkan bisa sesat atau salah. 


\section{Sunardi}

Melalui pembelajaran juga dapat kita melestarikan, mentransformasikan, dan menginternalisasikan nilai-nilai Islam kepada peserta didik, sehingga nilai kultural-religius yang dicita-citakan dapat berfungsi dan berkembang dalam masyarakat dari waktu-kewaktu.

Oleh karena itu perumusan tujuan pembelajaran harus tegas dan jelas karena tujuan pembelajaran merupakan inti dari seluruh pemikiran pedagogis dan perenungan filosofis.

Begitu juga dengan pembelajaran Ta"lim al-Muta"allim di MTsN Plandi Jombang memiliki tujuan yang telah dirumuskan sebelumnya, sehingga materi yang disampaikan dapat terarah sesuai dengan yang diinginkan. Sebagaimana hasil wawancara peneliti dengan Muhammad Syahir, S. Pd. selaku kepala MTsN Plandi Jombang sebagai berikut:

"Sebenarnya dengan adanya pembelajaran $\mathrm{Ta}^{\mathrm{ec}}$ lim alMuta"eallim di MTsN Plandi Jombang ini dan kami juga masukkan dalam kurikulum pembelajaran MTsN Plandi Jombang, harapan kami tidak ada yang lain adalah semoga dengan adanya pembelajaran $\mathrm{Ta}^{\mathrm{ec}} \mathrm{lim}$ alMuta"eallim ini apa yang menjadi Visi dan Misi serta tujuan MTsN Plandi Jombang lebih mudah dicapai.”(H. Muhammad Syahir, Kepala MTsN Plandi Jombang, Wawancara, 11 Maret 2013).

Penejelasan tersebut memebarikan gamabaran bahwa MTsN Plandi Jombang ini berupaya mengintergrasikan sistem pembelajran yang sudah umum dipakai menajdi pembelajran yang berkarakter Islam. Sementara pembelajaran Ta"lim alMuta "allim di MTsN Plandi Jombang memiliki fungsi dan 
tujuan agar lebih mudah tercapai Visi, Misi, dan Tujuan MTsN Plandi Jombang, sebagaimana yang tertuang dalam profil MTsN Plandi diantara tujuannya adalah:

a. Menumbuhkan kesadaran beribadah dalam kehidupan sehari-hari.

b. Mengoptimalkan kegiatan keagamaan dilingkungan madrasah dan lingkungan masyrakat.

c. Melaksanakan pembelajaran, bimbingan dan pelatihan secara optimal.

d. Menanamkan perilaku Islami dalam kehidupan sehari-hari.

Kemudian, Muhammad Syahir, menjelaskan sebagai berikut:

"Pembelajaran Ta"lim al-Muta"allim ini sangat berkaitan sekali dengan kedisiplinan siswa dimadrasah ini, seperti yang tampak sekali adalah ketika siswa bersama guru mereka bersikap hormat, sopan santun, begitu juga dengan teman-temanya. Kemudian dari segi kehadiran, anak-anak selalu hadir tepat waktu, tidak pernah ada yang bolos dan lain sebagainya."(H. Muhammad Syahir, Kepala MTsN Plandi Jombang, Wawancara,11 Maret 2013).

Jadi sebagaimana keterangan dari hasil wawancara diatas peneliti dapat menyimpulkan bahwa tujuan pembelajaran Ta"lim al-Muta"allim di MTsN Plandi Jombang adalah sebagai berikut:

a. Megajarkan siswa untuk berakhlakul karimah terhadap guru, teman dan lain sebagainya. 


\section{Sunardi}

b. Mendidik siswa untuk belajar disiplin.

c. Mengajar siswa untuk menghormati waktu.

d. Mangajar siswa untuk saling hormat-menghormati dan menghargai dengan sesama.

Begitu juga sebagaimana hasil pengamataan dan yang dirasakan ketika beberapa kali bersama siswa/siswi di sekolah tersebut ketika observasi pada tanggal 11 Maret 2013 memeng sangat menekankan kedisiplinan sehingga sangat tepat sekali apa yang di paparkan oleh Kepala MTsN Plandi Jombang seperti yang dijelaskan di atas. Begitu juga dengan adab atau akhlak siswa dan siswinya sangat baik sekali, terutama akhlaknya kepada guru dan temannya. Sebagaimana penjelasan siswa MTsN Plandi Jombang setelah peneliti mewawancari beberapa siswa, hampir jawabannya sama, mereka menjelaskan:

"Setelah saya diajarkan Ta" ${ }^{\text {ec }}$ im al-Muta"eallim, terutama di

MTsN Plandi Jombang ini, alhamdulillah saya semakin terinspirasi menerapkan nilai-nilai akhlak atau etika saya kepada orang tua, guru, teman dsb. semakain baik dan bagus dan saya masuk sekolah lebih disiplin." (Dendi Dwi, wawancara, Jombang ,18 Maret 2013).

Siti Ainun Jariah menambah, dia mengatakan:

"Dengan diajarkan Ta"lim al-Muta"allim di sekolah kami, maka pemahaman kami tentang agama lebih mengerti, kemudian hidupkami lebih baik dari 
sebelumnya.(Siti Ainun Jariyah, Wawancara, 18 Maret 2013).

Jumlah guru Ta"lim al-Muta"allim di MTsN Plandi Jombang sebagai mana hasil wawancara dengan siswa MTsN Plandi Jombang, Waka Kurikulum MTsN Plandi Jombang yaitu Erviningsih Setyorini, M.Pd. serta guru Ta"lim AlMuta"allim yaitu Dra. Nur"azah, M.Pd.I. mengatakan:

"Di MTsN Plandi Jombang untuk tahun ini yang mengajar Talim al-Muta ealim adalah dua orang, yaitu Dra. Nur"azah M.Pd.I khusus ngajar di kelas VII dan IX, dan Bahrotul Ilmiah, S.Pd.I, khusus ngajar di kkelas VIII.’(Lutfi Nurlaili, Wawancara, 17 Maret 2013).

Menurut keterangan ini peneliti dapat menyimpulkan bahwa guru Ta"lim al-Muta"allim di MTsN Plandi Jombang dari kelas VII sampai dengan kelas IX berjumlah dua orang yaitu Dra. Nur"eazah, M.Pd.I dan. Bahrotul Ilmiah, S.Pd.I.

2. Metode Pengajaran Ta"lim Al-Mut"allim di MTsN Plandi Jombang

Metode pengajaran dapat diartikan sebagai cara yang dipergunakan oleh pendidik dalam mengadakan hubungan dengan peserta didik pada saat berlangsung proses pembelajaran. Dengan demikian, metode pengajaran merupakan alat untuk menciptakan proses pembelajaran yang pada intinya agar mudah untuk mencapai tujuan.

Sebagai guru semestinya dalam proses pembelajaran harus mempertimbangkan metode yang akan digunakan 


\section{Sunardi}

sehingga peserta didik mudah menerima materi apa yang akan disampaikan. Sehingga ketika dalam pembelajaran, siswa tidak hanya duduk santai mendengarkan penjelasan guru didepan, namun tidak mengerti dan memahami isi materi yang disampaikan.

Oleh karena itu dalam pembelajaran Ta"lim alMuta"allim di MTsN Plandi Jombang berdasarkan hasil wawancara dengan Ustazah Dra. Nur"eazah, M. Pd. I. selaku guru pelajaran Ta"lim al-Muta"allim di MTsN Plandi Jombang, beliau menjelaskan:

"Dalam pembelajaran Ta"lim al-Muta"allim di MTsN Plandi Jombang khususnya kelas VII metode yang saya pakai adalah metode ceramah dan penugasan, karena pemahamannya masih rendah. Sedangkan di kelas IX metode yang saya gunakan adalah metode ceramah, diskusi, tanya jawab dan penugasan, karena pemahamannya sudah lebih tinggi."(Nur"azah, Guru Ta"elim Al-Mutaeeallim, Wawancar pribadi, 23 Maret 2013).

Sebagaimana hasil wawancara diatas, dapat peneliti simpulkan bahwa metode yang di gunakan oleh Dra. Nur"Azah selaku guru Ta"lim al-Muta"allim di MTsN Plandi Jombang, khususnya di kelas VII dan IX adalah metode ceramah, metode tanya jawab, metode diskusi dan metode penugasan. 
Kemudian peneliti mewawancarai siswa MTsN Plandi Jombang, tentang metode yang digunakan oleh guru Ta"lim alMuta" allim ketika mengajar, siswa tersebut mengatakan:

"Metode pengajaran Ta"lim al-Muta"allim yang dipakai di kelas kami adalah metode ceramah, tanya jawab, diskusi dan penugasan, tergantung materi yang disampaikan sehingga menurut kami lebih cepat memahami materi yang diajarkan." (Lutfi Nurlaili, wawancara, 16 Maret 2013).

Kemudian Siti Ainun Jariyah. Menambahka:

"Kalau pembelajaran Ta"e lim al-Muta"allim metode yang digunakan oleh bu Azah selaku guru Ta ${ }^{e e} \mathrm{lim}$ adalah kadang-kadang memakai metode ceramah, tanya jawab, dan dikasih tugas."(Nia, Wawancara, 18 maret 2013).

Jadi dari dua sumber ini, peneliti dapat menyimpulkan, bahwa metode yang digunakan dalam pembelajaran Ta"lim al-Muta"allim oleh Dra. Nur,Azah, M.Pd.I. selaku guru Ta"lim al-Muta"allim di MTsN Plandi Jombang khususnya di kelas IX adalah metode ceramah, metode tanya jawab, dan metode penugasan. Namun semua metode yang dipakai ini disesuaikan dengan materi yang disampaikan.

Sedangkan menurut penjelasan siswa kelas VII metode yang digunakan Dra. Nur"Azah, M.Pd.I. dalam pembelajaran Ta"lim al-Muta"allim di kelasnya siswa tersebut menjelaskan:

"Biasanya metode yang sering di pakai oleh bu Azah di kelas kami adalah metode ceramah, dan 


\section{Sunardi}

kadang-kadang menggunakan metode penugasan.”(Nia, Wawancara, 18 maret 2013).

Jadi sebagaimana diterangakan dari hasil wawancara tersebut peneliti dapat menarik kesimpulan di kelas VII MTsN Plandi Jombang, metode yang dipakai dalam pembelajaran Ta"lim al-Muta"allim ada dua yaitu metode ceramah dan penugasan.

Sedangkan sebagaiman yang dijelaskan oleh Dra. Nurreazah M. Pd.I, kitab yang dipakai dalam pembelajaran Ta"lim al-Muta"allim di MTsN Plandi Jombang, yaitu khusus untuk kelas VII kitab yang dipakai adalah kitab terjemah Ta"lim al Muta"allim ( Pedoman Belajar Pelajar dan Santri) yang di terbitkan oleh PT Al Hidayah Surabaya. Alasan Dra. Nureazah M. Pd.I, memberikan materi dengan kitab ini adalah karena pemahaman untuk siswa MTs itu masih minim sekali tenatang bahasa arab karena kebanyakan mereka lulusan dari SD.

Sedangkan untuk kelas IX, selain memakai terjemah Ta"lim al-Muta"allim ditambah dengan kitab terjemah Washaya al Abna" dengan alasan agar pemahaman tentang akhlak, etika dan lain sebagainya lebih luas.

Sedangakan untuk guru Ta"lim al-Muta"allim yang kedua yaitu Bahrotul Ilmiah, S.Pd.I. selaku guru kelas VIII MTsN Plandi Jombang ketika peneliti mewawacrai pada tanggal 29 Maret 2013 beliau menjelaskan untuk pembelajaran Ta"lim al-Muta"allim sebenaranya yang lebih mengerti dari pada saya adalah Ustaz. Drs. Syamsul Islam. H. M.PdI. karena beliau yang lebih lama mengajar di 
MTsN Plandi ini, sedangkan saya sebagai penggantinya dan baru mulai tahun ini. Oleh karena itu, maka peneliti mencari penjalasan kepada Drs. Syamsul Islam, H.M.PdI. tentang data yang dibutuhkan.

Metode-metode yang di disebutkan diatas dapat dijelaskan sebagai berikut:

a. Metode ceramah

Yang dimaksud dengan metode ceramah adalah memberikan penerangan dan penuturan secara lisan secara sepihak (oleh seorang guru) kepada muridmurid tentang kesatuan bahan pelajaran. Tujuannya agar bahan pelajaran tersebut dapat dipahami murid.

b. Metode tanya jawab.

Metode tanya jawab ialah cara penyampaian pelajaran dengan jalan guru mengajukan pertanyaan dan murid memberikan jawaban. Atau sebaliknya murid bertanya dan guru memeberikan jawaban.

c. Metode diskusi

Metode diskusi adalah percakapan ilmiah yang berisikan pertukaran pendapat, pemunculan ide-ide serta pengujian pendapat yang dilakukan oleh beberapa orang yang tergabung dalam kelompok untuk mencari kebenaran.

d. Metode pemberian tugas.

Metode pemberian tugas adalah cara penyajian bahan pelajaran dimana guru menugaskan murid-murid mempelajari sesuatu, kemudian harus dipertanggung jawabkan. 


\section{Sunardi}

B. Peran dan Tugas Guru dalam Mengimplementasi Nilai-nilai Ta"lim Al-Muta"allim dalam pembelajaran di MTsN Plandi Jombang

1. Peran guru dalam mengimplementasi nilai-nilai Ta ${ }^{e e} \lim A 1-$ Mutaeeallim dalam pembelajaran di MTsN Plandi Jombang

a. Guru sebagai pembimbing

Sebagaimana hasil wawancara, observasi, dan dokumentasi dapat peneliti paparkan bahwa peran guru dalam mengimplementasi nilai-nilai Ta"lim alMuta"allim di MTsN Plandi Jombang adalah semua guru berusaha untuk membimbing dan mengarahkan peserta didik untuk selalu mengajarkan perbuatanperbuatan positif yang mengarahkan kepada kebaikan. Dan melarang keras kepada semua peserta didiknya untuk melakukan perbuatan-perbuatan yang berbau negatif yang menjerumuskan kepada kesesatan atau dosa.

Sehingga di MTsN Plandi Jombang banyak mengadakan kegiatan-kegiatan yang bertujuan untuk menanamkan nilai-nilai Ta"lim al-Muta"allim pada siswa, dimana hal tersebut merupakan realisasi dalam pembelajaran. Contoh kegiatan-kegiatan tersebut adalah:

b. Sebagai pendamping dan imam Sholat dhuha, dhudur dan Sholat Jum ae at

Sholat dhuha adalah sholat yang sebagaian ulama" mengatakan hukumnya adalah sunnah muakkad, yaitu sangat diutamakan. Maka di MTsN 
Plandi Jombang juga berupaya mendidik siswanya untuk mengerjakan hal tersebut.

Sholat dhuha di MTsN Plandi Jombang dilaksanakan di Masjid Baitu Maemur MTsN Plandi Jombang secara berjamaah. Sholat ini dilaksanakan sekitar jam 09:30-10:00, yang diikuti oleh semua siswa dan siswi secara bergiliran. Kemudian, pendamping sholat dhuha ini adalah Wali Kelas dan guru-guru MTsN Plandi Jombang.

Ustaz. Drs. Syamsul Islam, H. M.Pd.I menjelaskan selaku ketua pembina keagamaan MTsN Plandi Jombang menjelaskan:

"Siswa MTsN Plandi Jombang diwajibkan untuk sholat sunnah dhuha secara berjamaah, untuk membisakan kepada mereka untuk senang melakasanakan sholat meskipun hukumnya sunnah, kemudian sholat jamaah zuhur, bahkan sholat jumat pun dilaksanakan di Masjid MTsN Plandi Jombang, yang lansung dipimpin oleh guru yang telah dijadwalkan, dalam rangka untuk membimbing dan membina mereka."'Syamsul Islam, Wawancara, 31 Maret 2013).

Jadi dari keterangan ini dapat peneliti simpulkan bahwa yang menjadi peran guru dalam mengimplementasi nilai-nilai Ta"lim al-Muta"allim d MTsN Plandi Jombang adalah guru sebagai pengarah, artinya siswa selain memahami teori yang disampaikan oleh guru, namun perlu dibiasakan 


\section{Sunardi}

melaksanakan apa yang diharapkan gurunya. Selanjutnya guru juga sebagai pembimbing, karena pada sholat dhuha ini yang memimpin sholat tersebut adalah Wali Kelas dan guru-guru MTsN Plandi Jombang sesuai yang telah dijadwalkan.

MTsN Plandi Jombang, selain membiasakan siswa dan siswinya untuk melaksanakan sholat sunnah, tidak ketinggalan juga untuk mendidik siswanya untuk mengerjakan sholat yang wajib secara bejamaah. Karena sebagaimana yang dijelaskan oleh Nabi SAW. bahwa sholat jamaah itu lebih utama dari pada sholat sendirian, yaitu dua puluh tujuh derajat.

Maka di MTsN Plandi Jomabang ini, berusaha mengajar siswanya untuk disiplin, terutama beribadah kepada Allah SWT. seperti sholat dhuhur dan sholat dhuha secara berjamah.

Sholat Dzuhur ini dilaksanakan pada jam 12:0012:30, di Majid Baitul Ma"mur MTsN Plandi Jombang, yang diikuti oleh siswa dan siswi MTsN Plandi Jombang secara bergiliran, kecuali hari sabtu. Kemudian didampingi oleh Wali Kelas dan guru-guru MTsN Plandi Jombang yang telah dijadwalkan.

c. Guru sebagai tauladan

Guru merupakan model atau tauladan bagi peserta didik dan semua orang menganggap sebagai guru. Terdapat kecendrungan yang besar untuk menganggap bahwa peran itu tidak mudah untuk ditentang, apalagi ditolak. Keperhatinan, kerendahan, 
kemalasan, dan rasa takut, secara terpisah ataupun bersama-sam.

Peran dan fungsi ini patut dipahami, dan tidak perlu menjadi beban yang memberatkan sehingga dengan ketrampilan dan kerendahan hati akan memperkaya arti pembelajaran.

Sebagai tauladan, tentu saja pribadi dan apa yang dilakukan guru akan mendapat sorotan peserta didik serta orang di sekitar lingkungannya yang menganggap atau mengakuinya sebagai guru. Sehingga sebagaimana yang peneliti amati ketika observasi dari tanggal 3 Oktober sampai 30 Desember 2012 di MTsN Plandi Jombang guru sangat berperan penting dalam mengajar peserta didiknya terutama dalam hal kedisiplinan, misalnya dalam segi kehadiran guru memberi contoh harus hadir tepat waktu. Kemudian kitika sholat guru memberi contoh atau tauladan kepada peserta didik atau siswa untuk mengerjakan sholat tepat waktu baik sholat sunnah dhuha atapun sholat dhuhur dengan cara berjamaah dan lain sebagainya.

Dra. Nureazah, M. Pd.I, menjelaskan bahwa dalam pembelajaran di MTsN Plandi Jombang itu sangat ditekankan masalah kedisiplinan sehingga setiap jam pelajaran yang beliau ajarkan sudah dibuatkan absen tersendiri untuk peserta didiknya.

d. Guru sebagai motivator

Guru merupakan Agen of chang pada peserta didik sehingga kegiatan belajar mengajar hendaknya 


\section{Sunardi}

ditujukan untuk mencapai tujuan yang sesuai dengan ajaran yang sudah diajarkan dalam al-Quran dan hadits. Di MTsN Plandi Jombang, Semua guru setiap mengajar tidak pernah jenuh, bosan, capek dan lain sebagainya memberikan motivasi sekaligus siraman rohani untuk mengajak siswa menanamkan pada dirinya dalam kehidupan sehari-hari tentang nilai-nilai yang Islami, walaupun mulai dari hal-hal yang kecil, terutama bagaimana berpakaian, berbuat baik kepada guru, orang tua, sesama teman, masyarakat, dan lebihlebih kepada Allah SWT.

Sebagaimana peneliti amati ketika ikut dalam upacara bendera tanggal 9 Oktober 2012 dimana yang mengisi sebagai pembina upacaranya adalah kepala sekolah MTsN Plandi Jombang. Sebagai isi dari ceramahnya diantaranya adalah lebih banyak memberikan motivasi dan masukan tentang bagaimana pentingnya ilmu, pentingnya kedisiplinan dalam menuntut ilmu. Begitu juga dengan dewan guru yang lain seperti Bu Mukhasonah, dan Faisal Victory.

e. Guru sebagai pengajar dan pendidik

Sebagaimana Imron, S. Ag.,(Imron, Wawancara, 29 Maret 2013), memaparkan cara-cara mengimplementasi nilai-nilai Ta"lim al-Muta"allim dalam pembelajaran di MTsN Plandi Jombang adalah sebagai berikut:

1) Ceramah terintegrasi dalam upacara bendera setiap hari senin. 
Dalam ceramah terintegrasi ini yang dimaksudkan adalah guru bertugas memberikan pelajaran atau ceramah yang tidak hanya berorientasi atau tertekan pada pelajaran yang umum saja namun lebih mengarah kepada pemberian masukan atau pembelajaran yang Islami. Guru juga mengajar tidak hanya didalam kelasa saja tapi diluar kelaspun guru berusaha memberikan bimbingan arahan dan lain sebagainya.

2) Ceramah terintegrasi dalam memberi pelajaran. setiap guru di intruksikan dapat mengintegrasikan ajaran iman dan takwa dalam materi pelajaran, kemudian tentang etika, akhlak, dsb.

3) Pondok Romadhan.

4) Ceramah penggajian dalam rangka pelepasan siswa kelas IX MTsN Plandi Jombang.

5) Beberapa Program yang lain mendukung:

a) Ibadah qurban secara iuran antara guru, karyawan dan siswa.

b) Lomba keagamaan (seni baca al-Qur"ean, azan, ceramah, dsb), pada penyambutan hari-hari besar.

Kemudian Ustaz. Imron, S. Ag, menambah:

"Harapan dari semua guru disini tidak ada yang lain dalam rangka mencetak generasi yang Islami, yang hidup berpedoman pada Al-Qur"an dan hadits. Karena dengan berbagai pertimbangan seperti relita 


\section{Sunardi}

saat ini banyak generasi yang mengaku Islam hanya sebagai sampel saja, namun nilai-nilai yang terkandung dalam ajaran Islam diabaikan.”(Imron, Wawancara, 29 Maret 2013),

2. Tugas guru dalam mengimplementasi nailai-nilai Ta"lim Al-Muta"llim dalam pembelajaran di MTsN Plandi Jombang

Tugas seorang pendidik atau guru tidak semata-mata hanya memindahkan ilmu pengetahuan, nilai-nilai atau sikap, dan ketrampilan, akan tetapi pendidik atau guru bertanggung jawab atas pengelolaan (menager of learning), pengarah (director of learning), fasilitator dan perencana.

Nur"azah, menjelaskan diantara tugas guru dalam mengimplementasi nilai-nilai Ta"lim al-Mutallim di MTsN Plandi Jombang adalah:

"Tugas guru adalah sebagai tauladan kepada peserta didik, yaitu memberikan contoh kepada siswa untuk berakhlak yag baik. Setelah itu, guru juga bertugas sebagai pengontrol, artinya guru harus mengawasi peserta didiknya sehingga mengerti permaslahan yang dilakukan anak didiknya, seperti, contoh setiap selesai sholat dhuha guru mengabsen siswanya supaya mengetahui siapa yang tidak sholat dhuha dan lain sebagainya."."(Nur"azah, Wawancara, 23 Maret 2013). 
Jadi peneliti menyimpulkan bahwa tugas guru dalam mengimplementasi nilai-nilai Ta"lim al-Muta"allim di MTsN Plandi Jombang adalah sebagai tauladan, artinya guru memeberikan contoh kepada peserta didiknya tentang bagaimana etika dan akhlak yang mulia. Kemudia tugas guru adalah sebagai pengontrol, artinya guru tidak hanya mengawasi siswa di kelas saja namun guru juga mengontrol siswanya walaupun di luar kelas, sehingga mengetahui siswa yang mana yang melanggar dan tidak melanggar.

Kemudian Ustaz. Syamsul Islam, menjelaskan diantara tugas adalah;

"Menurut saya yang paling urgen sebagai tugas guru dalam mengimplementasi nilai-nilai $\mathrm{Ta}^{\mathrm{ec}} \mathrm{lim}$ alMutaeeallim di MTsN Plandi Jombang adalah sebagai pengajar, yaitu guru mengajarkan pelajaran yang telah disusun dan melaksanakan penilaian setelah pembelajaran selsesia. Kemudian sebagai pendidik, yaitu guru mengarahkan muridnya kepada tingkat kedewasaan yang berkepribadian insan kamil seiring dengan tujuan Allah SWT dalam menciptakannya." (Samsul Islam, Wawancara, 29 Maret 2013).

Jadi menurut keterang diatas, peneliti dapat menyimpulkan tugas sebagai guru dalam mengimplentasi nilai-nilai Ta"lim al-Muta"allim di MTsN Plandi Jombang adalah pertama sebagai pengajar, artinya guru bertugas merencanakan program pengajaran kemudian mengajarkan program yang telah direncanakan tersebut, dan diakhiri 


\section{Sunardi}

dengan penilaian. Kedua, guru sebagai pendidik, yaitu guru bertugas untuk mengarah muridnya pada tingkat kedewasaan yang berkepribadian insan kamil sesuai dengan perintah Allah SWT.

Di MTsN Plandi Jombang juga sebagaimana hasil observasi dan wawancara, kebiasaan-kebaiasaan yang ditanamkan kepada siswa dalam rangka menanamkan nilainilai Ta"lim al-Muta"allim dalam kehidupan sehari-hari, yang merukan tugas sebagai seorang guru adalah:

1) Semua siswa MTsN Plandi Jombang sebelum mulai belajar di wajibkan untuk berdoa, dipandu oleh ketua kelasnya masing-masing.

2) Semua siswa MTsN Plandi Jombang wajib membaca al-Qurean, yaitu surat-surat pendek sebelum pelajaran dimulai.

3) Siswa MTsN Plandi Jombang dianjurkan untuk puasa senin dan kamis. Khusus puasa sunnah yang diutamakan, seperti puasa Asyura" dan lain sebagainya. Maka pada hari itu anak-anak diajak untuk puasa semuanya, kemudian semua kantin yang ada di lingkungn Madrasah dilarang untuk berjualan.

4) Siswa MTsN Plandi Jombang dibiasakan memberi salam dan senantiasa hormat kepada guru.

5) Siswa MTsN Plandi Jombang di anjurkan untuk selalu hidup bersih, dan sebainya. 


\section{Peran Guru Dalam Penerapan Nilai-Nilai Ta'lim Al-muta'allim}

\section{DAFTAR PUSTAKA}

Akhyak. Peneliti Jalan Pendidikan, Yogyakarta: Pustaka Pelajar, 2003

Nata, Abuddin. Persfektif Islam Tentang Strategi Pembelajaran, Jakarta: Kencana, 2009.

Alfiah dan Zalyanaau. Hadis Tarbawi, Yogyakarta: Zanafa Publishing.

Umar, Bukhari. Ilmu Pendidikan Islam, Jakarta: Amzah, 2010.

Departemen Agama RI, Syamil Alqur"an Miracle Thereference,Bandung: Sygma, 2010.

Rumayulis, H. Ilmu Pendidikan Islam, Jakarta: Kalam Mulia, 2002.

Slamet, M Yahya, "Atmosfir Akademik dan Nilai-Nilai Estetik Kitab Ta"lim al-Muta"allim, 'Laporan penelitian tidak diterbitkan" Porwokerto: P3M STAIN, 2005.

Mastuhu, Dinamika Sistem Pendidikan Pesantren,Jakarta: INIS, 1994.

Thaifuri. Muhammadun, Pedoman Belajar bagi Penuntut Ilmu Secara Islami, terj. Ta"lim Mut"allim Thoriq at-Ta"lim, Surabaya: Menara Suci, 2008.

Fathurrohman, Pupuh dan M. Sobry Sutikno. Strategi Belajar 


\section{Sunardi}

\section{Mengajar Melalui Penanaman Konsep Umum \& Konsep}

Islami,Bandung: PT Refika Aditama, 2009.

Ramayulis, Metodologi Pendidikan Agama Islam, Jakarta: Kalam Mulia, 2010. 